Behavioural and Cognitive Psychotherapy, 1999, 27, 383-385

Cambridge University Press. Printed in the United Kingdom

\title{
Obituary
}

\section{THE EGO, THE SPIRIT AND COGNITIVE THERAPY NAGY BISHAY: 27 JULY 1936-3 MARCH 1999}

Nagy Bishay was born in 1936 in Cairo, Egypt, the eldest son of a lawyer. He decided to pursue a medical career and after his medical training in Cairo, he joined the army as a general practitioner and soon pursued his interest in psychological medicine and gained its diploma. He practised psychiatry in 1965 in different military hospitals, was particularly interested in military psychiatry during the 1967 war, and wrote his MD thesis on the study of hysterical fits among young adult males under the stress of military service.

He came to England in 1975, seeking to further his experience and training and in pursuit of improving his therapeutic skills. He trained as a senior registrar in psychiatry in the West Midlands Regional Health Authority and took up his post as consultant psychiatrist at the North Manchester General Hospital in 1980. He had an initial interest in psychoanalysis and group analytic psychotherapy, then was introduced to cognitive therapy in 1982, a tool he continued to develop and use with passion for the remainder of his years.

His greatest academic and research contribution is his work on cognitive therapy for morbid jealousy. He proposed a cognitive behavioural formulation to explain the clinical and psychological features of non psychotic morbid jealousy as well as the selfperpetuating nature of the condition. Theoretically, this model provides a useful framework for differentiating normal from morbid jealousy but also should open up alternative treatment avenues for a condition that is notoriously difficult to treat.

Nagy enjoyed swimming, walking, playing chess and family outings, but his greatest passion was for God, whom he served with perseverance, sincerity, and commitment. He was a founder member of the Coptic Orthodox Church in Manchester. He served as a Treasurer for over 20 years, a job he did quietly and with great humility. He was a committed Christian who had the capacity to use part of himself in a facilitative way to help patients who were believers. He identified the difficulties that patients with strongly held religious beliefs pose to the cognitive therapists and proposed examining the relevant statements in the various holy texts, such as the Torah, Bible, and Koran, supported by daily life experiences if possible to help see an alternative religious concept.

Nagy believed in the need to integrate traditional psychological and spiritual insights and in the lack of distinction between the process of achieving mental growth and spiritual growth. I was gently teased by him for my interest in dynamic psychotherapy; however, we tended to agree on the conclusion, that whichever model you prefer, in order to escape previous experience and free ourselves from "transference", or "negative thoughts", it is necessary that we "learn". We must continually expand our

(C) 1999 British Association for Behavioural and Cognitive Psychotherapies 
knowledge and field of vision through the thorough digestion and incorporation of new information. This process of expansion of knowledge and learning something new requires a giving up of the old self and a death of outworn knowledge. We begin by distrusting what we already believe by deliberately challenging the validity of what we have previously been taught and hold dear- "our schema". This is the way to mental and spiritual growth.

He emphasized the shared ground between client and therapist as a strategy for dealing with as sensitive an issue as religion. Through working within the patient's own system beliefs, helping him to examine it critically and rationally so that, together, any thought distortions or unusual assumptions can be identified and corrected. He wrote about emotional disturbance as a consequence to how events are being evaluated: as a reward from a loving God, as a punishment from an angry God, as a lesson from a teaching God, as unintended by a kind but not intervening God, or as the will of a mysterious God. Instead, illness can be evaluated as a blessing, a test or a means to discipline God's beloved children.

He had a significant influence upon the careers of a number of trainee psychiatrists, was a keen teacher, established an endowment fund to further training in cognitive therapy and developed video tape training material in cognitive behavioural psychotherapy. He wrote widely on the use of cognitive behavioural therapy in the management of a variety of conditions from neurosis to psychosis and developed his own culturally relevant material for training. Nagy spent a great deal of his time listening, comforting and supporting his patients, friends and colleagues. His love and kindness touched the lives of many. He was always warm, accepting and nonjudgmental, and he had tremendous enthusiasm and devotion to his work and welfare of the patient.

Nagy was diagnosed with cancer in September 1998, he took it with faith. He was asked by a colleague how he felt about his illness, and replied in his usual serene manner, "If I live, I live. If I die, I'm ready ...”. He was ready to meet with God whom he served faithfully. He spent the last few weeks in hospital, surrounded by his family and many friends. In his hospital bed, as he was struggling with consciousness, I held his hand and I felt a pressure.... I hoped that he knew how valued and loved he was.

In an article published the day he died, he described a brief cognitive intervention to deal with life events and the loss of loved ones. He wrote, "Normalize grief and comfort believers in the hope of meeting again in the next life..." He leaves a wife and three wonderful children, one of whom is a medical student. In a tribute given by his daughter, Mary, she thanked God for her dad and the most precious gift he gave them - their faith. Nagy's family have shown tremendous faith and courage coping with their loss. Their beliefs concurred with his and his teachings. His spirit lives on.

Laila Daud

\section{References}

Bishay, N. R. (1966). Cognitive distortions of religious concepts and their treatment. Behavioural Cognitive Bulletin of the Psychotherapy Section of the Royal College of Psychiatrists, 4, 20-28.

Bishay, N. R. (1999). Cognitive therapy of psychosis in clinical practice. Psychiatric Bulletin, 23, 167-169. 
Bishay, N. R. et al. (1989). An uncontrolled study of cognitive therapy for morbid jealousy. British Journal of Psychiatry, 154, 386-389.

Bishay, N. R. et al. (1996). Morbid jealousy: A cognitive outlook. Journal of Cognitive Therapy: An International Quarterly, 10 (1).

TARrier, N. et al. (1990). Morbid jealousy: A review and cognitive behavioural formulation. British Journal of Psychiatry, 157, 319-326. 